\author{
Magdalena Brodacka (D) https://orcid.org/0000-0001-6102-1284 \\ Uniwersytet Jagielloński \\ magdalenabrodacka@gmail.com
}

\title{
W lustrze literatury - czesko-polski mit środkowoeuropejski i jego przeobrażenia
}

\author{
In the Mirror of Literature. The Czech-Polish Central European Myth and Its \\ Transformations
}

\begin{abstract}
The article In the Mirror of Literature. The Czech-Polish Central European Myth and Its Transformations is an attempt to outline the transformations of the Central European myth, which consists of the Habsburg myth and its transformations expressed in the works of Austromodernists after 1918; the revival of the Central European myth, which took place after the Second World War and was connected with the post-totalitarian regime introduced in the countries belonging to the Soviet Bloc; and the posttransformation period - from the 1990s to the present. The comparative juxtaposition of Polish and Czech literature allows us to trace the development, transformation, and silencing of the myth of Central Europe, which at the same time expresses the identity problems of both nations.
\end{abstract}

Keywords: myth, Central Europe, Polish literature, Czech literature, identity

Streszczenie: Tekst W lustrze literatury - czesko-polski mit środkowoeuropejski i jego przeobrażenia jest próbą zarysowania przemian mitu środkowoeuropejskiego, na który składają się kolejno: mit habsburski oraz jego kolejne ujęcia w twórczości austromodernistów po 1918 roku; odrodzenie mitu Europy Środkowej, które nastąpiło po drugiej wojnie światowej i związane było z ustrojem posttotalitarnym wprowadzonym w państwach należących do bloku sowieckiego; okres potransformacyjny - od lat dziewięćdziesiątych XX wieku do chwili obecnej. Komparatystyczne zestawienie literatury polskiej i czeskiej pozwala na prześledzenie rozwoju, transformacji i wyciszenia mitu Europy Środkowej, który jednocześnie wyraża problemy tożsamościowe obu narodów.

Słowa kluczowe: mit, Europa Środkowa, literatura polska, literatura czeska, tożsamość

Mówiąc o Europie Środkowej, nie sposób pominąć aspektu geograficznego, którego istota wyrażona jest już w samej nazwie - geograficzny środek określa 
się względem dwóch skrajnych kierunków, w tym wypadku Wschodu i Zachodu ${ }^{1}$. Dziś są to w znacznym stopniu pojęcia kulturowe, które raczej dookreślają tożsamość Europejczyków, niż wyznaczają faktyczny, horyzontalny podział kontynentu na trzy części. Problem ten zobrazowała słowacka artystka mulitmedialna, Ilona Németh, która na kolorowej odbitce mapy Europy zaznaczyła aż dziewięć jej środków. Dokonała tego na podstawie postawionych, głównie w latach dziewięćdziesiątych XX wieku, pomników środków Europy w Niemczech (dwa pomniki), Austrii, Polsce, Białorusi, na Słowacji, Węgrzech, Litwie i Ukrainie:

Projekt Środki Europy, 2006-2010 skupia się na tym, w jaki sposób twierdzenia uchodzące za ścisłe i naukowe stają się relatywne w świetle tożsamości narodowej. Autorka pokazuje i ironicznie podważa dążenia różnych narodów do „znalezienia” geograficznego centrum Europy na własnym terytorium² ${ }^{2}$.

Nauki ścisłe i społeczne stają się bezsilne w zetknięciu z kulturową i tożsamościową narracją narodów, które podporządkowują sobie geografię na rzecz własnych wyobrażeń i roszczeń do bycia środkiem Europy, a nie jej peryferiami. By zaradzić tej bezsilności, niektórzy badacze sięgają po termin „geografia wyobrażona", który ma tłumaczyć mechanizmy tworzenia się kulturowych pojęć tożsamościotwórczych. Zastanówmy się, czym jest „geografia wyobrażona" i czy pozwala na pełniejsze zrozumienie fenomenu Europy Środkowej.

W 1983 roku Benedict Anderson opublikował książkę Wspólnoty wyobrażone i wykazał w niej nierozerwalny związek między tożsamością i narracją, dzięki której retrospektywnie wytworzona zostaje biografia narodu. Badacz podkreślił konstytutywną rolę obszaru (zamieszkanego przez daną wspólnotę) oraz języka, które sprawiają, że obywatele narodu wzajemnie się nie znając, tworzą między sobą więzi z zachowaniem wewnętrznego pluralizmu. Kategoria wyobrażenia zakotwicza zatem trwanie danej wspólnoty w historii przez nadawanie sensu kolejnym wydarzeniom społeczno-historycznym. To konstytuowanie sensu i wartości narodowych odbywa się w teraźniejszości, co Anderson nazywa fikcją zakorzenioną w rzeczywistości. Jednocześnie dzięki kategorii wyobrażenia wspólnoty i narody wykonują gest skierowany ku przyszłości - objawia się on w działaniach imperialistycznych związanych z dominacją gospodarczą i kulturową, która niejednokrotnie przeobrażała fizyczną mapę świata. Poszczególne państwa Europy Środkowej w XX wieku oscylują między podporządkowaniem

1 Coraz częściej zwraca się jednak uwagę na to, że horyzontalny podział Europy ustępuje nowemu oglądowi w linii wertykalnej północ-południe. Takie spojrzenie postulują między innymi Przemysław Czapliński w książce z 2016 roku Poruszona mapa. Wyobraźnia geograficzno-kulturowa polskiej literatury przetomu XX i XXI wieku oraz Marek Cichocki w książce z roku 2018: Pótnoc i Potudnie. Teksty o polskiej kulturze i historii.

2 Opis pracy Ilony Németh Środki Europy, 2006-2010, Nieuchwytny środek (Europy), „Herito” 2013, nr 10, s. 25. 
imperialistycznej polityce Habsburgów, Rzeszy Niemieckiej czy Związku Radzieckiego a tworzeniem narracji - mit środkowoeuropejski jest jedną z nich o choćby kulturowej rzeczywistości alternatywnej. Na podobne zagadnienie wskazuje Simona Škrabec w książce Geografia wyobrażona, która inspirując się myślą Andersona o tym, że pisanie - konstytuowanie tożsamości - zawsze odbywa się post factum, wyraźnie podkreśla oksymoron wpisany w termin geografii wyobrażonej ${ }^{3}$. Mapa fizyczna nie pokrywa się z mapami mentalnymi opisywanymi często za pomocą takich terminów, jak pogranicze, centrum lub peryferia. Anderson przypomina, że wyobrażenie rzutowane jest na różnego rodzaju mapy, które stają się uprzednie wobec rzeczywistości, niejako ją antycypując $c^{4}$.

Jednym z przykładów praktyk konstruowania wyobrażonej wspólnoty jest XVI-wieczna mapa Europy stworzona przez niemieckiego kartografa Johannesa Putscha. Stary Kontynent jest na niej zobrazowany w postaci dziewicy, której piersi - symbol serca - stanowiły Czechy i ich stolica Praga. Czesi częściej niż środkiem Europy nazywali siebie jej sercem5.

Określenie Czech jako „środka” Europy, a Pragi jako jej „serca” zawiera przy tym mocny akcent wartościujący. Metafora serca oznacza bowiem nie tylko życiowe "centrum” w sensie biologicznym; w sercu - dobrym, szlachetnym, prawym etc. lokujemy wszak tradycyjnie to, co w człowieku najlepsze, najwartościowsze. W ten sposób pojęcie „środka” uzyskuje swój kolejny wymiar - etyczny. A przy

3 Por. S. Škrabec, Geografia wyobrażona. Koncepcja Europy Środkowej w XX wieku, tłum. R. Sasor, Kraków 2013, s. 263.

4 Por. B. Anderson, Wspólnoty wyobrażone. Rozważania o źródtach i rozprzestrzenianiu się nacjonalizmu, tłum. S. Amsterdamski, Kraków 1997, s. 167-174. Elżbieta Rybicka poświęciła mapom literackim rozdział swojej książki Geopoetyka. Przestrzeń i miejsce we wspótczesnych teoriach i praktykach literackich, Kraków 2014, s. 142-167.

5 Zob. „Někdy v 15. století vrcholí sebestylizace Čechů jako nového Izraele, vyvoleného národa, který je lídrem Evropy a křestanstva. Někdy v 16. století se to v protestantském, i katolickém prostředí transformovalo do vizualizace - "coeur Europe«, „»srdce Evropy«. To jsou ty slavné mapy. Začíná to Johannem Putschem v roce 1537, kdy je Evropa zobrazována jako panna (»in forma virginis«) a na jejích prsou je jako medaile »srdce Evropy« (»coeur Europe«), a to jsou Čechy a Praha. Takže Čechy - srdce Evropy. Toto heslo zdánlivě 19. století je zkrátka mnohem staršı'”. [W XV wieku w Czechach dochodzi do głosu wyobrażenie Czechów o sobie jako o Nowym Izraelu, narodzie wybranym, który stoi na czele Europy i chrześcijaństwa. W XVI wieku zarówno wśród katolików, jak i protestantów koncept ten przeobraził się w figurę serca Europy. To są przecież te popularne mapy. Zaczęło się to od Johanna Putscha, który w 1537 roku przedstawił mapę Europy jako dziewicę, a na jej piersiach, niczym medal, umieścił serce Europy, czyli Czechy i Pragę]. Unos středni Evropy, rozmowa V. Kučery z J. Rychlíkiem, V. Bělohradskim i P. Hlaváčkiem, https://ct24.ceskatelevize.cz/archiv/1508592-unos-stredni-evropy, dostęp: 10.02.2019. O tym, że do dzisiaj Czesi bardziej niż o Środku Europy myślą o sobie jako jej sercu, mówi Jiří Trávníček w rozmowie Europa Środkowa, bijace serce kontynentu. Rozmowa zJirím Trávničkiem, http://www.presseurop.eu/pl/content/article/251081-europa-srodkowa-bijace-serce-kontynentu, dostęp: 1.08.2017. 
tym istnienie takiego „środka” jest jedną z najgłębszych potrzeb egzystencjalnych człowieka $^{6}$.

XVI-wieczny przykład Pragi jako serca Europy poza znaczeniem etycznym wskazuje jeszcze, że potrzeba wpisania istnienia narodu w konkretne miejsce na mapie oraz w konkretną hierarchię, którą ta mapa ustanawia, było obecne w bardzo odległych historycznie czasach. Europa Środkowa nie jest więc ideą, która zrodziła się pod wpływem XX-wiecznych totalitaryzmów. To raczej pojęcie czerpiące żywotne soki z centralnego - wyróżniającego - miejsca na mapie, które przez wieki wojen i okupacji zmieniało wielokrotnie swój kształt i nazwy.

Jeśli zatem to nie geografia i polityka na stałe definiują środkowoeuropejskość, jeśli wydają się bezradne w obliczu przemian historycznych, migracji kultur i idei, to dlaczego Europa Środkowa, choć pozornie niedefiniowalna, jest pojęciem z powodzeniem używanym zarówno w dyskursie naukowym, jak i tym codziennym. Skąd jej popularność, której dowodzą międzynarodowe konferencje, festiwale i nagrody literackie odwołujące się do tego pojęcia; dlaczego na uniwersytetach poświęca się jej osobne kursy, a liczne wydawnictwa specjalizują się w wydawaniu pisarzy środkowoeuropejskich? I wreszcie, skąd ciągle żywotne rozbieżności w wyznaczeniu środka Europy przez poszczególne państwa?

Pewną wskazówką może być odpowiedź Aleksandra Fiuta, która częściowo tłumaczy powyższe wątpliwości i mnogość definicji: „Jak widać, jedną z najbardziej uderzających cech idei Europy Środkowej jest to, że zrodziła się ona w wyobraźni i sercu pisarzy-wygnańców i zagościła głównie na papierze. Zamieszkała, rzec można, w słowie" 7 . To właśnie potrzeba stworzenia narracji o własnej wyjątkowości i odrębności na mapie Europy wiąże się, z jednej strony, z potrzebą kompulsywnego podtrzymywania jednostkowości i wagi państw Europy Środkowej, a z drugiej - z pragnieniem kompensacji kompleksu niższości w stosunku do dwóch wielkich podmiotów (Zachodu i Wschodu). Na pierwszą z tych potrzeb wskazuje Claudio Magris:

Każda granica wiąże się z poczuciem zagubienia i potrzebą pewności. Granica jest koniecznością, bo bez niej, czyli bez wyodrębnienia, nie ma tożsamości, nie ma

6 J. Baluch, Idea „środka” a tożsamość czeskiej kultury [w:] Kundera. Materiaty z sympozjum zorganizowanego w Katowicach w dniach 25-26 kwietnia 1986 r., red. J. Illg, Londyn 1988, s. 12. Jacek Baluch przywołuje kolejno autorów, którzy w swoich dziełach podejmowali temat Czech jako serca Europy: J.A. Komenský, Labyrint svèta á raj srdce; F.X. Šalda, Pokušení Pascalovo; F. Palacký, Dëjiny národu českého v Čechách a na Moravě dle pưvodních pramenư; V. Macura, Znameni zrodu; M. Kundera, Zaktad czeski; Zachód porwany albo tragedia Europy Środkowej.

A. Fiut, Być (albo nie być) Środkowoeuropejczykiem, Kraków 1999, s. 22. 
formy, nie ma indywidualności i nie ma nawet realnej egzystencji, ponieważ zostaje ona wchłonięta przez chaos i niezróżnicowany byt ${ }^{8}$.

Natomiast przyczyny mechanizmu kompensacji przywołuje Fiut, gdy wskazuje tematy, które wyróżniają literaturę środkowoeuropejską. Wspomina o: nieakceptowanej peryferyjności, która rodzi się z kompleksu niższości; poczuciu ruchomości granic z powodu przebywania w obszarze pogranicza oraz związanej z tym problematycznej tożsamości ${ }^{9}$.

Mieszkaniec Europy Środkowej być może częściej niż innych regionów Starego Kontynentu w XX wieku był zmuszony do objaśniania i problematyzowania swojej tożsamości zależnej od wydarzeń historycznych i związanych z nimi traum, migracji, życia na pograniczach kulturowych i językowych oraz ciągłej zależności od silniejszych militarnie bądź gospodarczo sąsiadów. Właśnie taki obraz „małego narodu” przedstawił Milan Kundera w swoim głośnym eseju Zachód porwany albo tragedia Europy Środkowej z 1983 roku, tłumacząc, że „mały naród to taki, którego istnienie może zostać w każdej chwili zakwestionowane, który może zniknąć i o tym wie" ${ }^{10}$. Pytanie o sens własnego istnienia i możliwości przetrwania świadczy o swoistej kondycji psychologiczno-kulturowej Środkowoeuropejczyków. Jeśli historia i polityka zbyt często pukają do drzwi małych narodów, to właśnie kultura pełni funkcję kompensacyjną i ocalającą tożsamość. Stąd wciąż żywa popularność mitu środkowoeuropejskiego, który, na co wskazuje oprócz Aleksandra Fiuta także Claudio Magris, jest jedynie tym, co istnieje w słowie, a jego obiektywna realność wyraża się za pomocą transfiguracji ${ }^{11}$.

I właśnie owe transfiguracje - sposoby wyrażania mitu środkowoeuropejskiego i jego kolejne przeobrażenia w literaturze XX i XXI wieku - stanowią cel niniejszego artykułu. $Z$ racji moich kompetencji i zainteresowań szczególnie uważnie skupię się na literaturze polskiej i czeskiej ${ }^{12}$. Wybrane przykłady literackie pomogą mi nakreślić długą linię trwania mitu Europy Środkowej. Składają się na nią tak zwana Mitteleuropa i mit habsburski, „Zachód porwany”

8 C. Magris, O demokracji, pamięci i Europie Środkowej, tłum. J. Ugniewska, Kraków 2016, s. 260.

9 A. Fiut, dz. cyt., s. 24.

10 M. Kundera, Zachód porwany albo tragedia Europy Środkowej, „Zeszyty Literackie” 1984 , nr 5, s. 24.

11 Zob. C. Magris, O demokracji, pamięci i Europie Środkowej, dz. cyt., s. 54.

12 Pragnę zaznaczyć, że w niniejszym tekście to właśnie pisarze czescy będą przywoływani najczęściej. W twórczości Bohumila Hrabala, Josefa Škvoreckiego, Oty Pavla, Milana Kundery czy Jáchyma Topola Europa Środkowa pojawia się eksplicytnie, a autorów zwykło się nazywać środkowoeuropejskimi. Literatura polska jest pod tym względem wyraźniej zróżnicowana, a wskazują na to już same jej określenia, takie jak literatura małych ojczyzn, kresowa, galicyjska czy pogranicza. Sposób, w jaki twórcy środkowoeuropejscy - polscy i czescy - opisują samych siebie oraz własną twórczość, uważam za niezwykle znamienny, a komparatystyczne zestawienie wydobywa różnice, z których środkowoeuropejskość jest ulepiona. 
przez komunizm oraz dzisiejsza wspólnota państw europejskich. Chcę jednak podkreślić, że linia ta nie jest prostą prowadzącą z jednego punktu na mapie $i$ historii do drugiego. Ma ona raczej charakter koła - często powraca do przeszłości, zasadza się na powtórzeniu, zagarnia coraz to nowe przestrzenie, tworzy mityczne centra i ich pogranicza. W samą strukturę mitu wpisana jest, z jednej strony, idealizacja przeszłości, a z drugiej - polemika z nią, a wręcz dekonstrukcja zastanych narracji. Jestem tym samym świadoma niebezpieczeństw, które może rodzić niezwykle uogólniający mit środkowoeuropejski. Przede wszystkim zawłaszcza on w swoje struktury wiele państw i regionów, pozwala wierzyć w monolityczność Europy Środkowej oraz propaguje wizję ocalałej kultury, która stoi na antypodach zmurszałego już Zachodu. Czy Europa Środkowa nie stała się zatem ofiarą własnego mitu?

\section{Powrót do źródeł}

Początki mitu środkowoeuropejskiego sięgają XIX wieku, przyniósł on bowiem nowe narracje tożsamościowe i państwowe w całej Europie. Wówczas narodziło się pojęcie „Mitteleuropy”, które według Jacques’a Le Ridera oznacza „mapę umysłową kultur niemieckojęzycznych"13, należy przy tym podkreślić odrębność Rzeszy Niemieckiej proklamowanej w 1871 roku od monarchii Habsburgów. W wieku XX, a konkretnie po 1915 roku, Mitteleuropa zyskała popularność dzięki książce Friedricha Naumanna o tytule Mitteleuropa właśnie, w której autor zdefiniował geopolitykę niemiecką związaną z germanizacją terenów środkowoeuropejskich. Panowanie Habsburgów dla wielu obywateli i obserwatorów było gwarantem federacyjnej idei Europy Środkowej, która stanowiła ochronę przed polityką imperialną Zachodu i Wschodu. Bardzo dobrze wyraził to Franciszek Palacký, twierdząc, że gdyby Austrii nie było, należałoby ją po prostu wymyślićc ${ }^{14}$. Twierdzenie to lokuje się po jednej ze stron dość schizofrenicznego podziału, który zdominował dyskurs odrodzeniowy XIX-wiecznych działaczy czeskich walczących o wskrzeszenie i autonomiczny status kultury czeskiej.

Vladimír Macura dobrze zobrazował to rozszczepienie w swojej książce $C z e-$ ski sen, a konkretnie w eseju Sen o Europie. Według badacza wiek XIX (a zwłaszcza Wiosna Ludów), przyniósł ze sobą podstawowe pytanie o czeską tożsamość wpisaną jednocześnie w dwa konteksty: europejski i niemiecki.

13 J. Le Rider, „Mitteleuropa”, środkowoeuropejskie miejsce pamięci, tłum. O. Mastela, „Pamiętnik Literacki” 2013, nr 4, s. 5.

14 Zob. F. Palacký, Dějiny národu českého v Čechách a na Moravě dle pưvodních pramenů, t. 1, Praha 1948; J. Baluch, Idea „środka” a tożsamość czeskiej kultury, dz. cyt. 
Założenie, że Europa jest odpowiednim kontekstem dla czeskich spraw i postrzeganie jej świata jako obcego i wrogiego w obu przypadkach miało na celu demonstrację czeskości jako wyjątkowej i istotnej wartości ${ }^{15}$.

Szczególne środkowoeuropejskie usytuowanie wśród innych narodów wchodzi jednocześnie w polemikę z ideą germańskiej Mitteleuropy, której Czesi przeciwstawiali wspólnotę Słowian: „W naszym kraju, podobnie jak w przypadku rosyjskich słowianofilów, panslawizm został zaakceptowany jako wartość, która może zastąpić świat europejski, a przynajmniej zdecydowanie go odnowić i odmłodzić"16.

Le Rider słusznie zauważa, że Mitteleuropa z czasem staje się pojęciem coraz bardziej ambiwalentnym - z mitycznej federacji państw zjednoczonych pod władzą cesarza Franciszka Józefa pozostają realne starcia kulturowe i germanizacja najdalszych ziem wchodzących w skład monarchii. Zniknięcie z mapy Europy w 1918 roku wielkiego imperium Habsburgów i jednoczesny napór polityczny Rzeszy Niemieckiej wskrzeszają mit habsburski, a raczej jego nową transformację, gdzie współistnienie i wielokulturowość narodów odczytywano w kategoriach nowoczesnego kosmopolityzmu. Le Rider konkluduje: „Jeśli zastanowić się nad relacją między mitem habsburskim a realiami monarchii habsburskiej, można stwierdzić, że ta ostatnia odnosiła w całej przestrzeni naddunajskiej skutek integrujący - w znaczeniu, jakie przypisuje się dzisiaj wyrazowi globalizacja" ${ }^{17}$. Magris już w panowaniu ostatniego cesarza monarchii austro-węgierskiej dostrzegał „mityczną transfigurację zmierzchu (...). Żółtawy i błotnisty Dunaj staje się modry, a przed polityczno-historyczną katastrofą ludzie szukają ucieczki w ulotnym, sentymentalnym i rozkosznym ziemskim raju" ${ }^{18}$. W książce Mit habsburski w literaturze austriackiej moderny eseista wykazuje, jak na przykładzie literatury austriackiej mechanizm zapomnienia i zacierania tego, co nieuniknione, przekształca się w nową wersję mitu, w którym dźwięki walca i śmiech operetki zagłuszają coraz donośniejszą melancholię.

Melancholia ta wywołana jest odchodzeniem obrazu Europy federacyjnej, ideału cesarstwa ponadnarodowego, które miało być lekarstwem na rodzące się wówczas nacjonalizmy przy jednoczesnym odwracaniu wzroku od napięć między narodami. Biurokratyczny rygor i rytm pracy przełamywany był zmysłowym, radosnym hedonizmem i czasem wolnym spędzanym w kawiarniach -

15 „Přijetí Evropy jako odpovídajícího kontextu českých záležitostí i její vnímání jako světa cizorodého a nepřátelského v obou případech sloužilo jedinému cíli demonstraci problému češství jako zvláštní a důležité hodnoty”. V. Macura, Sen o Evropě [w:] Český sen, Praha 1998, s. 65.

16 „U nás stejně jako u ruských slavjanofilů bylo slovanství přijímáno jako hodnota, která může evropský svět nahradit, nebo alespon rozhodným způsobem obrodit, omladit”. Tamże, s. 69.

17 J. Le Rider, dz. cyt., s. 9.

18 C. Magris, Mit habsburski w literaturze austriackiej moderny, tłum. E. Jogałła, J. Ugniewska, Budapeszt-Syrakuzy-Kraków 2019, s. 257. 
domach artystów ${ }^{19}$. Przed wybuchem pierwszej wojny światowej dualistyczna monarchia austro-węgierska liczyła ponad 50 milionów obywateli przeróżnych narodowości: Czechów, Węgrów, Słoweńców, Chorwatów, Serbów, Bośniaków, Rumunów, Polaków, Włochów, Rusinów i innych ${ }^{20}$. Powodowało to nieustanne konflikty i osłabienie Cekanii. Po 1918 roku na mapie Europy ponownie zmieniono granice - tym razem na tyle restrykcyjnie, że z ogromnej monarchii pozostała mała Republika Austriacka zamieszkiwana przez jedynie sześć milionów mieszkańców. Powstanie nowych państw nie przekreśliło jednak dziedzictwa kulturowego, zwłaszcza literackiego, które wytworzyło się przez kilkadziesiąt lat trwania wielokulturowej i wielojęzykowej monarchii: „Mit habsburski nie tylko nie umarł wraz z końcem cesarstwa, lecz wydaje się, że wraz z nim rozpoczął swój najbardziej urokliwy i interesujący okres"21.

Jest to jednak okres bardzo krytycznej rewizji mitu i jego powieściowej dekonstrukcji. Według amerykańskiej badaczki Marjorie Perloff to właśnie austromoderniści ${ }^{22}$, czyli pisarze austriaccy, którzy tworzyli w czasie tak zwanej długiej wojny między 1918 a 1945 rokiem, mierzyli się z rozpadem dotychczasowego idealizowanego świata wielokulturowości i przeczuli największe tragedie XX wieku, które miały przyjść kilkanaście lat później wraz z drugą wojną światową: "Jak gdyby ten chylący się ku upadkowi świat stanowił sprzyjającą okazję do subtelnego, czułego i dyskretnego zrozumienia człowieka”23. W książce Ostrze ironii Perloff omawia twórczość pisarzy, którzy dokonali swoistej dekonstrukcji mitycznych Austro-Węgier, a jednocześnie są „synami” ziem podległych dawnej monarchii ${ }^{24}$.

19 Zob. tamże, s. 355.

20 Zob. M. Perloff, Ostrze ironii. Modernizm w cieniu monarchii habsburskiej, tłum. M. Płaza, Wrocław 2018, s. 15.

21 Tamże, s. 54.

22 Austromodernizm to formacja kulturowa, którą Marjorie Perloff nazywa i analizuje w swojej książce Ostrze ironii. Istnienie austromodernizmu i jego twórców - Eliasa Canettiego, Josepha Rotha, Roberta Musila, Karla Krausa, Paula Celana i Ludwika Wittgensteina - badaczka łączy ze schyłkiem monarchii Habsburgów i upadkiem dotychczasowego porządku świata, zwłaszcza Europy. Okres kataklizmu i swoistego końca historii, na które przypadła twórczość austromodernistów, Adam Lipszyc w posłowiu do dzieła Perloff nazywa „zbłąkanym postimperium” i zaznacza jednocześnie, że „autorka nie skupia się na wąsko pojętych "pisarzach austriackich» (...). Książkę Perloff zaludniają raczej sieroty po imperium, urodzone na jego obrzeżach lub nawet - jak Paul Celan - już po jego upadku, kluczące po świecie, który utracił grawitacyjne centrum”. A. Lipszyc, Apokaliptyczna precyzja, czyli Austria „irret in orbe ultima”, posłowie [w:] M. Perloff, dz. cyt., s. 318.

23 M. Perloff, dz. cyt., s. 30.

24 Stąd również próby wypracowania nowej narracji tożsamościowej, która nie będzie tylko gestem nostalgii za utraconym światem, ale przede wszystkim stanie się narzędziem rozpoznania nowej epoki i jej zagrożeń. Perloff analizuje ośmiusetstronicowy dramat Karla Krausa Ostatnie dni ludzkości i wskazuje na technikę kolażu opartą na zasłyszanych cytatach, fragmentach z ówczesnych gazet, problematyzuje funkcję plotki dziennikarskiej i podkreśla tym samym złożoność prawdy, jej zmienność pod wpływem mediów i wyobrażeń oraz zapośredniczenie języka. 
Analizując ich dzieła, badaczka wyznaczyła podstawowe cechy literatury austromodernistycznej. Są nimi: figura ironii, jako nadrzędna w rozumieniu rzeczywistości i budowaniu tekstu; złożony stosunek autora do własnego (choć nie tylko) żydostwa, w tym - w niektórych wypadkach - wyraźny antysemityzm; wyjątkowy stosunek do pierwszej wojny światowej, wywołującej traumę destrukcji kultury austriackiej ${ }^{25}$; zamiłowanie do paradoksów i nieustanne podważanie wartości normatywnych; poczucie outsiderstwa, dzięki któremu pisarze tamtego obszaru potrafili spojrzeć na własne dzieje z boku, a w końcu tworzenie w języku niemieckim (w jego austriackiej odmianie) - języku ojczystym i wybranym zarazem: „Niemczyzna stała się u astromodernistów niezwykle świadoma - była ona nie tylko środkiem komunikacji, ile przedmiotem refleksji" ${ }^{26}$.

Pewien opór przed jednoznacznym oglądem i nazywaniem obserwowanego świata wydaje się dość naturalny dla twórców, którzy wychowali się w państwach byłej monarchii habsburskiej. Emil Brix, komentując związek Wiednia $\mathrm{z}$ innymi miastami środkowoeuropejskimi, przywołał dwie koncepcje, które dobrze obrazują relacje społeczne w samej Cekanii i na terenach po jej rozpadzie. Pierwsza koncepcja odnosi się do dzieła Eliasa Canettiego Masa i wtadza, w którym pisarz zauważa, że zbyt duża bliskość, na przykład sąsiedztwo poszczególnych narodów w Monarchii, może powodować strach: „Ta myśl jest do głębi środkowoeuropejska, gdyż «dotknięcie» przez różne tożsamości - bliskie a jednocześnie obce - jest w tej części regionu powszechne, w przeciwieństwie do jednoznacznie zachodniej lub wschodniej części Starego Kontynentu"27. Natomiast drugą koncepcję Brix przypisuje Zygmuntowi Freudowi - innemu wybitnemu mieszkańcowi Wiednia, który dowiódt, że człowiek zawsze oddala się od tego, co zbyt podobne do niego: „Kiedy coś jest zbyt blisko nas i posiada podobne cechy, wówczas wywołuje w nas lęk i odgradzamy się od tego wyraźniej niż od czegoś, co jest dalekie"28. Nie są to cechy typowe jedynie dla tego regionu geograficznego, jednak wydaje się, że to właśnie w środku Europy szczególnie wyraźnie dochodziły do głosu tego typu napięcia.

Czesi, dryfujący między kulturą europejską i niemiecką stworzyli modelową kontrnarrację wyróżniającą ich nowo powstałą państwowość - Czechosłowację -

Omawiając Marsz Radetzky'ego Josepha Rotha, badaczka odwołuje się do lustrzanej kompozycji powieści, która wciąga swoją dwuznacznością, pozostawia wiele niedopowiedzeń i jednocześnie obnaża porządek cesarstwa, jego przepisy, regulacje i ceremoniał, maskujące wewnętrzny rozkład. W Cztowieku bez wtaściwości Roberta Musila Perloff podkreśla rolę narratora, który jest ironicznym obserwatorem w świecie niezrealizowanych potencjalności, każdy problem oświetlany jest z wielu perspektyw, a brak akcji zastępują eseistyczne rozważania i refleksje. W autobiografii Eliasa Cenettiego Ocalony język zwraca szczególną uwagę na relację między używanym językiem a tożsamością.

25 Zob. M. Perloff, dz. cyt., s. 19.

26 Tamże, s. 35.

27 E. Brix, Z Zowrotem w Europie Środkowej. Eseje i szkice, tłum. A. Śliwa, Kraków 2012, s. 59 .

28 Tamże. 
na mapie Europy. Utworem, który na dobre zapisał się w historii literatury czeskiej, były Przygody dobrego wojaka Szwejka, które w latach 1921-1923 stworzył Jaroslav Hašek. Tytułowy bohater, modelowy głupi Jasio i sprytny łobuz zarazem $^{29}$, zgłasza się na ochotnika do wojska austriackiego po zamordowaniu arcyksięcia Ferdynanda w Sarajewie. Jak sam tłumaczy:

Walczyć będę (...). Z Austrią klapa. U góry włażą nam już do Krakowa, a na dole pchają się do Węgier. Młócą nas jakby żyto jakie, gdzie spojrzeć lanie, i dlatego wołają mnie na wojnę. Przecież czytałem pani wczoraj gazetę, jako drogą ojczyznę naszą spowity niejakie chmury.

- Ale przecież pan się ruszać nie może.

- To nic nie szkodzi, pani Mullerowo, pojadę na wojnę na wózku³

Hašek epatuje ironią i groteską, wprowadza swojego antybohatera w przestrzeń szpitala psychiatrycznego, który z jednej strony jest metaforą dogorywającej Cekanii, a z drugiej tylko w nim można zachować jasność umysłu i „uwolnić się" od nie-swojej wojny. Warto podkreślić, że pisarz sięga po podobne zabiegi literackie, co wspomniani wcześniej austromoderniści. Pisał o tym Kundera:

Tu właśnie ujawnia się podobieństwo (podobieństwo niezwykłe, nieoczekiwane) między hermetycznym Kafką a ludycznym Haškiem. (...) Podobnie jak system sprawiedliwości u Kafki, wojsko o Haška jest jedną wielką instytucją biurokratyczną, militarną administracją, dla której nie mają już żadnej wagi odwieczne cnoty (odwaga, spryt, zręczność) ${ }^{31}$.

Obok Kafki i Haška z powodzeniem wymienić można Brunona Schulza, który w tym samym czasie na kartach swojej poetyckiej prozy wytworzył mitologię galicyjskiego miasteczka Drohobycz. Również i on, konstruując swój osobny wszechświat, dekonstruuje znany mu dobrze mit habsburski ${ }^{32}$. Schulz przywołuje wszechobecny portret Franciszka Józefa I:

29 „Ale nie brakowało też powiązań zmierzających w zupełnie innym kierunku. W. Slawista, A.M. Ripellino rozpoczyna swoją Pragę magiczną od spotkania na Moście Karola Józefa Szwejka z Józefem K. z Procesu F. Kafki; pol. ilustrator powieści Haska, Andrzej Czeczot, przedstawił S. z czaszką w ręku, czyniąc go ironicznym porte parole Hamleta; czy wreszcie czes. poeta Vladimir Vokolek w czasach obowiązującego socrealizmu pisał do szuflady powieść Tako rzecze Szwejk, której bohater stawał się Zara-Szwejkiem, wcieleniem Zaratustry Nietzschego". J. Baluch, P. Gierowski, Švejk [w:] tychże, Czesko-polski stownik terminów literackich, Kraków 2016, s. 373.

30 J. Hašek, Przygody dobrego wojaka Szwejka podczas wojny światowej, tłum. P. Hulka-Laskowski, t. 1, Warszawa 1980, s. 30.

31 M. Kundera, Sztuka powieści, tłum. M. Bieńczyk, Warszawa 2015, s. 60.

32 O Brunonie Schulzu jako pisarzu z gruntu środkowoeuropejskim pisał Błażej Szymankiewicz Bruno Schulz - pisarz środkowoeuropejski?, „Zeszyty Naukowe Towarzystwa Doktorantów Uniwersytetu Jagiellońskiego” 2016, nr 4. Autor odwołuje się do biografii twórcy związanego z Wiedniem, lektur i spotkań innych środkowoeuropejskich pisarzy, analizuje pograniczność 
Świat był wówczas ograniczony Franciszkiem Józefem I. Na każdej marce pocztowej, na każdej monecie i na każdym stemplu stwierdzał jego wizerunek niezmienność świata, niewzruszony dogmat jego niejednoznaczności. Taki jest świat i nie masz innych światów prócz tego - głosiła pieczęć z cesarsko-królewskim starcem. Wszystko inne jest urojeniem, dziką pretensją i uzurpacją. Na wszystkim położył się Franciszek Józef I i zahamował świat w jego wzroście ${ }^{33}$.

Inercję czasową monarchii Schulz przełamuje Rewolucją Wiosenną. Pytanie o czas - wielkiej Historii i małych opowieści mieszkańców - wydaje się niezwykle angażować bohaterów przywołanej już literatury środkowoeuropejskiej. Czas mityczny cyrkuluje i ciągle odnawia się w rozmaitych wariacjach literackich i płynie zupełnie obok linearnej narracji historycznej. Kolejne mity wypierają bądź przeobrażają swoje wcześniejsze wersje, świat powieściowy wydaje się nimi bezpowrotnie zainfekowany. Jednocześnie pokazuje on, że literatura podejmująca dialog z mitem środkowoeuropejskim w jego przeróżnych odmianach podtrzymuje ciagłość trwania narodów, regionów i wspólnot, na przekór zmianom geopolitycznym.

\section{Drugie życie mitu, czyli tragedia Europy Środkowej}

Po 1945 roku doszło do kolejnego poruszenia mapy. Emil Brix zauważa, że „Po drugiej wojnie światowej Wiedeń stał się Zachodem a Kraków Wschodem”34. Nowa strefa wpływów w Europie przesunęła granice Wschodu w kierunku Zachodu tak, że dotychczasowa idea środka została niemal wymazana z mapy. Okazało się, że Wiedeń, który leży na wschód od Pragi, nie należy do strefy wpływów Związku Radzieckiego, natomiast Czesi od wieków związani z kulturą Habsburgów nagle zostali utożsamieni z gospodarczym opóźnieniem i polityczną dyktaturą Wschodu. Najtrwalsza zmiana dokonała się natomiast w samym micie środkowoeuropejskim, w którym powoli zanikał obraz idealnej monarchii austro-węgierskiej, a jego kolejna transformacja dokonała się w literaturze państw należących do bloku socjalistycznego.

Simona Škrabec zauważa, że wyrugowanie z mapy przestrzeni Europy Środkowej, która w wielu wyobrażeniach i narracjach pełniła funkcję mostu między Zachodem a Rosją, przyczyniło się do utrwalenia granicy-muru pomiędzy

Drohobycza i wreszcie samą twórczość Schulza. Mityzację rzeczywistości z perspektywy dziecka oraz jej konkretny wpływ na prozę Andrzeja Kuśniewicza, Juliana Stryjkowskiego i Włodzimierza Odojewskiego opisała z kolei Ewa Wiegandt w swoim klasycznym już dziele Austria Felix, czyli o micie Galicji w polskiej prozie wspótczesnej, Poznań 1988.

33 B. Schulz, Wiosna [w:] tegoż, Sanatorium pod Klepsydra, Kraków 2008, s. 88-89.

34 E. Brix, dz. cyt., s. 19. 
tymi dwoma światami ${ }^{35}$. Również Magris zwrócił uwagę na fakt, że idea środka Europy - mostu międzykulturowego - może przekształcić się w granicę:

Granica jest czymś dwoistym i dwuznacznym; czasami to most służący do spotkania drugiego, czasami bariera mająca go od nas oddzielić. Niekiedy to obsesja polegająca na uporczywym umieszczaniu kogoś lub czegoś po drugiej stronie; literatura jest między innymi wyprawą w poszukiwaniu sposobu, aby obalić ów mit tamtej strony, zrozumieć, że każdy znajduje się raz na tym, raz na tamtym brzegu, że każdy jak w średniowiecznym misterium, jest tym Drugim ${ }^{36}$.

Tę likwidację mostów na swój artystyczny sposób przewidział wcześniej Franz Kafka w jednym z najbardziej bolesnych opowiadań o tytule Most: „Most nie był jeszcze zaznaczony na mapie. - Tak leżałem i czekałem; musiałem czekać. Raz zbudowany most, jeśli nie runie, nie przestaje być mostem" ${ }^{37}$. W zakończeniu tej miniatury most obrócił się, by spojrzeć, kto go krzywdzi, i sam runął $\mathrm{w}$ przepaść.

Metafora mostu ewokuje myślenie o przekraczaniu granic, zarówno tych geograficznych, jak i kulturowych. Jednak, jak słusznie wskazuje Radosław Zenderowicz, na moście nie da się żyć, nawet wówczas, gdy pełni on funkcję łącznika ${ }^{38}$. Metaforyczne zburzenie mostu umocniło granicę podziału Starego Kontynentu na dwie strefy wpływów, utrwalając przy tym nową metaforę zawłaszczającą drugą połowę XX wieku, a mianowicie metaforę muru. Według Przemysława Czaplińskiego „Być ulokowanym na osi poziomej to brać udział w dziwnej kinetyce: trzeba z całych sił przemieszczać się na Zachód, aby pozostając na swoim miejscu, oddalać się od Wschodu" ${ }^{39}$. Od lat pięćdziesiątych XX wieku szeroko rozumiany Zachód stał się ziemią obiecaną i mityczną Atlantydą, do której szczególnie dążyli Czesi, Słowacy, Węgrzy i Polacy. Zlikwidowanie muru stało się więc wspólnym celem tych wszystkich państw. Jednak, jak celnie zauważa Janusz Sepioł:

Do Jałty nie byliśmy [z Czechosłowacją - dop. M.B.] wspólnotą w żadnym sensie tego słowa. Wspólny okazał się natomiast los powojenny: sowiecka strefa wpływów, przejęcie różnymi drogami władzy przez komunistów, forsowana industrializacja, RWPG i Układ Warszawski i co jakiś czas wstrząs polityczny kończący się militarną interwencją lub stanem wojennym, po którym następowała fala emigracji ${ }^{40}$.

35 Zob. S. Škrabec, dz. cyt., s. 47-48.

36 C. Magris, O demokracji, pamięci i Europie Środkowej..., dz. cyt., s. 252.

37 F. Kafka, Most, tłum. R. Karst [w:] tegoż, Okno na ulicę i inne miniatury, tłum. R. Karst, A. Kowalkowski, Gdańsk 1996.

38 R. Zenderowicz, Środkowoeuropejskość jako transnarodowa tożsamość [w:] Europa Środkowa. Salon czy przedpokój Europy?, red. A.K. Gogacz, Łódź 2010, s. 47-66.

39 P. Czapliński, dz. cyt., s. 13.

40 J. Sepioł, Smutek Wyszegradu, „Herito” 2013, nr 10, s. 29. 
Ta wspólnota powojennego losu sprawiła, że mit Europy Środkowej odżył na nowo i ponownie stał się nieodłączną składową tożsamości państw, które nie godziły się na swój narzucony z zewnątrz los.

Lata siedemdziesiąte i osiemdziesiąte przynoszą według Vladimíra Macury powrót do myślenia kategoriami metafory środka Europy. Powrót ten, za którym stoi cała nowa mitologia, osadzony jest na mechanizmie straty i ponownej kompensacji braku.

Europa Środkowa jest bowiem postrzegana jako najgłębsze ucieleśnienie esencji europejskiej, jako rdzeń europeizmu. Różnorodność Europy Środkowej, rozumiana niemal jako jej genetyczna właściwość, jest przedstawiana jako ratunek przed unifikacją, której podlega Europa Zachodnia, a także przed monolitycznym, jednakowym Związkiem Radzieckim jako coś nieskończenie różnorodnego i żywego ${ }^{41}$.

Najpełniej dyskusje te ujawnią się w bogatej eseistyce prowadzonej na łamach czasopism. Pierwszy zabrał głos Milan Kundera, publikując w 1968 roku w dwutygodniku „Listy” esej o tytule Czeski los. Los ten jest według pisarza w znacznej mierze zdeterminowany położeniem geograficznym Czech, które od stuleci są uzależnione od politycznych decyzji swoich mocarstwowych sąsiadów. $\mathrm{Na}$ Kunderowską metaforę losu składał się jeszcze jeden element, a mianowicie rola kultury, edukacji i krytycznego myślenia, które Czesi wypracowywali już od czasów odrodzenia narodowego. W lutym 1969 roku w czasopiśmie „Tvár” Václav Havel napisał swoją polemiczną odpowiedź, tytułując ją przewrotnie Czeski los?. Jego zarzuty zostały skierowane głównie przeciwko mechanizmowi usprawiedliwiania położeniem geograficznym własnych niepowodzeń, małości politycznej i gospodarczej. Havel zarzucał Kunderze tworzenie nowej mitologii, która wytłumaczy cierpienia Czechów, gdy tymczasem Czechosłowacji potrzebni są odważni i uczciwi obywatele. Milan Kundera odpowiedział na zarzuty swojego kolegi po piórze tekstem Radykalizm i ekshibicjonizm w roczni$\mathrm{ku}$ „Host do domu”. Udowadniał on znaczenie moralne i potencjał kulturowy, które niosły ze sobą wydarzenia Praskiej Wiosny, tak potrzebnej nie tylko Czechom, ale i pozostałym Europejczykom, w tym Polakom. Praska Wiosna stała się niemal emblematem losu Środkowoeuropejczyka ${ }^{42}$.

41 „Střední Evropa je totiž chápána jako nejvlastnější ztělesnění evropské podstaty, jako jádro evropanství. Rozmanitost Střední Evropy, vnímaná témeř jako její genetická vlastnst je nabízena jako záchrana proti unifikaci, jíž podléhá Západní Evropa, i proti monolitnímu, zglajchšaltovanému Rusku jako cosi, co potenciálně je či spíše byl nekonečné mnochotvárné a živoucî'. V. Macura, dz. cyt., s. 72. Dodatkowo Macura zaznacza, że dyskuje o Europie Środkowej w latach siedemdziesiątych i osiemdziesiątych (zwłaszcza podczas Praskiej Wiosny) sięgają do przywołanych już przeze mnie wcześniej tematów XIX-wiecznych związków Czechów ze wspólnotą Słowian i Europą Zachodnią spod znaku Niemiec.

42 Dyskusję tę, prowadzoną na łamach czasopism, szczegółowo przywołał Andrzej S. Jagodziński w tekście Milan Kundera w polemikach [w:] Kundera. Materiaty z sympozjum..., dz. cyt., s. 21. 
Jednak dopiero esej Kundery Zachód porwany albo tragedia Europy Środkowej z 1983 roku na dobre rozsławił mit środkowoeuropejski, zwłaszcza wśród zachodnich odbiorców. W latach osiemdziesiątych pisarz miał już obywatelstwo francuskie, a jego książki cieszyły się coraz większą popularnością na Zachodzie. Do tej pory powiedziano niezwykle dużo na temat tego eseju ${ }^{43}$ (choć sam Kundera od lat nie zgadza się na jego przedruk). Ciągle jednak warto podkreślać, że pisarz jest w swoim myśleniu spadkobiercą i kontynuatorem mitu austromoderny ${ }^{44} \mathrm{i}-\mathrm{co}$ więcej - w swoim tekście dopuszcza się wielu uproszczeń i uogólnień, stosuje bogatą metaforykę, przyczyniając się tym samym do kreacji nowego mitu. Ewa Graczyk podkreśla, że politycznej koncepcji Kundery nie sposób rozpatrywać w oderwaniu od jego powieściopisarstwa:

Posługuje się Kundera w tym eseju całym szeregiem kategorii, chwytów, które wypracował w swoich powieściach. Występują u niego dwa zjawiska, które łączą się ze sobą: eseizacja powieści, ale także bardzo wyraźna fabularyzacja dyskursu. (...) Europa Środkowa, Zachód i Związek Radziecki tworzą w tym tekście miłosny trójkąt, którego podskórne istnienie emocjonalizuje i dramatyzuje dyskurs, i to powoduje, że ma on taką nośność dla wielu ludzi ${ }^{45}$.

Wystarczy sięgnąć po Ksiegę śmiechu i zapomnienia, by zauważyć cały zbiór motywów powtórzonych później w Zachodzie porwanym. Inni pisarze czescy równie często i chętnie podejmowali temat Europy Środkowej. Była ona przestrzenią rozgrywania się akcji ich powieści, przyczyniła się do stawiania ważkich pytań i wymusiła dawanie świadectwa czasom, w których żyli i tworzyli. Josef Škvorecki w swojej debiutanckiej powieści Tchórze z 1956 roku pisał, że „Kostelec leżał w samym środku Europy”" ${ }^{46}$ Tatuś z opowiadania Śmierć pięknych saren Oty Pavla 1971 kupił „Najdroższego karpia nie tylko w Czechosłowacji, ale w całej Europie Środkowej”“7, a narrator Zbyt gtośnej samotności Bohumila Hrabala uważał, że „Europa Wschodnia nie zaczyna się za Bramą Porzeczną, ale dopiero tam, gdzie kończą się stare austriackie dworce w stylu empire,

43 Szczególnie wartościowa jest dyskusja o wizji Europy Środkowej w eseistyce Milana Kundery, którą prowadzili ze sobą członkowie wspomnianego już sympozjum z 1986 roku.

44 Jacek Baluch podkreśla, że: „Kiedy po raz pierwszy próbuje Kundera przybliżyć Francuzom dziedzictwo kultury Europy Środkowej, wymienia obok Haška Kafkę, obok Bohuslava Martinů Schönberga i Bartóka, Freuda, Brunona Schulza i Gombrowicza, Déryego i Miloša Formana. (...) Geniusz żydowski stanie się w Zachodzie porwanym... najważniejszym według Kundery żywiołem dla kulturalnego fenomenu Europy Środkowej”. J. Baluch, dz. cyt., s. 17.

45 Graczyk w dyskusji z uczestnikami kunderowskiego sympozjum. Zob. taż, Dyskusja o Środku Europy [w:] Kundera. Materiaty z sympozjum..., dz. cyt., s. 36.

46 J. Škvorecký, Tchórze, tłum. E. Witwicka, Katowice 1970, s. 44.

47 O. Pavel, Śmierć pięknych saren, tłum. A. Czcibor-Piotrowski, Warszawa 2015, s. 14. 
gdzieś tam w Galicji, dokąd dotarł grecki tympanon"48. Literatura czeska bardzo aktywnie budowała i podtrzymywała odrodzenie narracji środkowoeuropejskiej, która nie tylko była jedną z podstawowych składowych tożsamości czeskiej, wyraźnie tłamszonej zwłaszcza w okresie „normalizacji”, ale także niezwykle aktywnie ten „nadmiar historii” przepracowywała. Warto w tym miejscu przywołać słowa Hrabala, który niejako definiuje powinności pisarza środkowoeuropejskiego:

Dziś wiem, że ta moja sinusoida w rzeczywistości jest także sinusoidą mojego narodu, że jestem medium społeczeństwa i środowiska, w którym żyję... A ponieważ od dzieciństwa żyję w Europie Środkowej, ponieważ mieszkam w samym sercu Europy, dopiero teraz w pełni pojmuję, że zarówno na mnie, jak i na tym moim pisaniu odcisnęły piętno wydarzenia polityczne, a chociaż czasem ich nie akceptuję, muszę w końcu się z nimi pogodzić, ponieważ są... (...), a zatem jestem świadkiem, dożyłem tego, że mogę opisać to uczucie, kiedy jestem co prawda poraniony drzazgami złamanej epoki, ale jednocześnie jestem zaszczycony, że mogę dać o tym świadectwo, że mogę tworzyć rękopis o końcu jednej epoki i początku nowej ${ }^{49}$.

Stosunek polskich pisarzy do idei Europy Środkowej po 1945 roku był nieco odmienny. Liczni badacze wskazują, że dla Polaków myślenie o sobie jako o sercu Europy nigdy nie było tak wyraźne i oczywiste jak dla Czechów. Bycie „pomiędzy” - w charakterze pogranicza kulturowego dużo lepiej definiowało polską tożsamość. Jak twierdzi Roman Zimand, wynika to z faktu, że „nasze związki ze Wschodem były zawsze silniejsze i bardziej konfliktowe niż w przypadku Czechów" ${ }^{\text {". }}$. Rzeczpospolita sięgała daleko na Wschód, a Polacy zbyt dotkliwie doświadczyli dominacji Rosji, dlatego narracja odróżnienia się od niej u nas dominowała ${ }^{51}$. Według Jerzego Illga „myśmy się raczej określali jako przedmurze chrześcijaństwa, w kategoriach geopolitycznych, ale nigdy nie było dla nas tak ważne, żeby być środkiem - jak dla Czechów"52.

W polskiej literaturze przedwojennej echa anegdoty, światów wyobrażonych i dekonstrukcji mitu habsburskiego są obecne między innymi u Brunona Schulza i Józefa Wittlina, a ironia i niedowierzanie historii na przykład w twórczości Witolda Gombrowicza. Według Aloisa Woldana po 1945 roku mit habsburski w znacznej mierze pokrywał się z mitem Galicji, a narracje, które w tym czasie powstały, pełniły funkcję kompensacyjną: „W swej literackiej formie mit

48 B. Hrabal, Zbyt gtośna samotność, tłum. P. Godlewski, Izabelin 2003, s. 32.

49 Tenże, Odnaleziona Ósemka, tłum. A. Kaczorowski [w:] tegoż, Piękna rupieciarnia, tłum. A. Kaczorowski, J. Stachowski, Wołowiec 2019, s. 97, 99.

50 R. Zimand, Dyskusja o Środku Europy [w:] Kundera. Materiaty z sympozjum..., dz. cyt., s. 32 .

${ }^{51}$ Pisze o tym Czapliński w rozdziale Wschód czyli bród Europy [w:] tegoż, Poruszona mapa..., dz. cyt.

52 J. Illg, Dyskusja o Środku Europy [w:] Kundera. Materiaty z sympozjum..., dz. cyt., s. 44. 
ten nie jest bynajmniej fenomenem małopolskim, czyli obecnym na terenach niegdyś przynależnych Austrii, lecz ogólnopolskim zjawiskiem wynikającym z pewnego napięcia między "starą " Austrią a "nową" Polską" ${ }^{3}$. Do rodzimych autorów, którzy mierzyli się z rzeczywistością stalinowskiej „nowej” Polski i sięgali po mit habsburski, zaliczyć można między innymi Andrzeja Kuśniewicza, Andrzeja Kijowskiego czy Kazimierza Brandysa. Ewa Wiegandt poddała dodatkowej analizie twórczość pisarzy z Galicji wschodniej, wytwarzając tym samym pojęcie „książek galicyjskich, [które - M.B.] konstruują mity po to, by je poddać zabiegom demistyfikującym" ${ }^{4}$. Jednocześnie lata siedemdziesiąte i osiemdziesiąte przyniosły ze sobą fascynację literaturą czeską, którą traktowano w kategorii lustrzanego odbicia ${ }^{55}$. Nie oznacza to jednak, że pojęcie Europy Środkowej na gruncie polskim było jedynie sztucznie przeszczepioną narracją.

Wprost przeciwnie - w emigracyjnych polskich czasopismach toczono wieloletnie ożywione dyskusje o tożsamości środkowoeuropejskiej. Jak wiadomo, zwłaszcza dwa periodyki okazały się najważniejsze dla kształtowania się tej refleksji: paryska „Kultura” oraz znacznie młodsze „Zeszyty Literackie”. Według Weroniki Parfianowicz-Vertun:

środowisko paryskiej „Kultury” odgrywało rolę ideowego przewodnika dla działań związanych z Europą Środkową. Jej redaktora Giedroycia i wieloletniego publicystę Mieroszewskiego uznać można za inicjatorów środkowoeuropejskich debat, a także twórców jednej z najbardziej przenikliwych wizji politycznego ładu w tej części Europy ${ }^{56}$.

„Kultura” była orędowniczką stworzenia federacyjnej wspólnoty państw Europy Środkowo-Wschodniej. Poszerzenie środka o Wschód - a konkretnie Ukrainę, Litwę i Białoruś - stanowiło gest poparcia dla działań emancypacyjnych sąsiadów. Za najwybitniejszych eseistów tematyki środkowoeuropejskiej i kresowej uznać można Jerzego Stempowskiego i Stanisława Vincenza, których zarówno działalność pisarska, jak i życie prywatne ogniskowało się wokół dwóch zasadniczych mitów: habsburskiego i jagiellońskiego. W latach

53 A. Woldan, Mit Austrii w literaturze polskiej, http://www.polska-niemcy-interakcje.pl/ articles/show/26, dostęp: 28.05.2019.

54 E. Wiegandt, Mit Galicji w polskiej prozie wspótczesnej (rekonesans tematologiczny), „Teksty: teoria literatury, krytyka, interpretacja” 1979, nr 5, s. 62.

55 „Własne spory (komunizm stwarza we wszystkich krajach Środka podobne problemy) możemy zobaczyć w innych polemikach, w innym wykonaniu, przy innym rozkładzie akcentów. Literatura czeska (...) wypowiada wiele spraw wyraziściej, niż my to potrafimy zrobić (...). Zainteresowanie Kunderą tutaj w Polsce bierze się między innymi stąd, że pisze on jakby o nas, ale jednocześnie obcość jest na tyle wyraźna, że możemy na wiele rzeczy spojrzeć bez tego - często potwornego emocjonalizmu i martyrologii, które tak dręczą i często ograniczają polskie myślenie o kulturze, komunizmie i Rosji”. E. Graczyk, dz. cyt., s. 36.

56 W. Parfianowicz-Vertun, Europa Środkowa w tekstach i dziataniach. Polskie i czeskie dyskusje, Warszawa 2016, s. 299. 
siedemdziesiątych i osiemdziesiątych w środowisku „Kultury” przepracowano mit jagielloński, który sugerował, że wielokulturowa koegzystencja Polaków, Litwinów, Ukraińców i Białorusinów jest tym samym doświadczeniem, które Czesi i Węgrzy nazywają Europą Środkową ${ }^{57}$.

„Zeszyty Literackie” z kolei stworzyły osobny dział - „Europa Środkowa”, w którym Barbara Toruńczyk prezentowała prozę i poezję środkowoeuropejską. Kwartalnik ten dążył do utrwalenia kanonu literatury środkowoeuropejskiej, oddając głos uznanym już pisarzom, wśród których znaleźli się między innymi: Milan Kundera, Tomas Venclova, Timothy Garton Ash, Josif Brodski czy Czesław Miłosz. Pismo, w którym opublikowano Zachód porwany albo tragedia Europy Środkowej Kundery, wyspecjalizowało się w literackim eseju. Po roku 2000 ważnym autorem związanym z kwartalnikiem stał się Claudio Magris, który wskazywał na kulturową niezwykłość dziedzictwa austromodernizmu.

Oprócz debat na temat narracji tożsamościowej, które toczyły się na łamach czasopism, warto wspomnieć o rzeczywistym spotkaniu pisarzy z całego świata - również tych z Europy Środkowej i Rosji - którzy w maju 1988 roku, w przededniu nowej epoki politycznej i kulturowej, przyjechali do Lizbony, by wziąć udział w międzynarodowej konferencji poświęconej literaturze. To wówczas, jak wskazuje zapis rozmów, pisarze rosyjscy (najwyraźniej zaskoczeni poglądami kolegów po piórze z innych krajów), musieli ustosunkować się do tej kulturowo-politycznej koncepcji. Jednym z zaproszonych pisarzy z Polski był Miłosz, który środkowoeuropejskość poszerzył o wschód - Litwę i południe - kraje byłej Jugosławii. Broniąc tezy o zasadności idei Europy Środkowej, Miłosz sformułował jeden z głównych, według niego, wyznaczników literatur środkowoeuropejskich, a mianowicie „wpływ historii na kształtowanie się jednostki” ${ }^{58}$. Jednocześnie pisarz podkreślił, że „Koncepcja Europy Środkowej nie została stworzona przez Kunderę. (...) Idea Europy Środkowej to antysowiecka koncepcja wynikająca z okupacji tych krajów. Ma ona w oczywisty sposób charakter antysowiecki" ${ }^{\prime 2}$. Z wypowiedzi tej można wyciągnąć co najmniej dwa wnioski: pierwszy, że pojęcie Europy Środkowej w literaturze polskiej sięga zdecydowanie odleglejszej przeszłości niż druga połowa XX wieku; a drugi, że to właśnie wspólne doświadczenie polityczno-historyczne cementuje ideę kultury środkowoeuropejskiej, a pisarze są tego świadkami.

Życie w epoce „nadmiaru historii” prowokuje pytania o powinności pisarzy-świadków swoich czasów. Miłosz pytał:

Co się dzieje w sytuacji, w której polski, węgierski czy litewski pisarz postanawia odpocząć od „tu i teraz”, zająć się tematem miłości i śmierci? Czy znajdzie się w tej

57 Tamże, s. 346.

58 C. Miłosz, Rozmowy zagraniczne 1979-2003, tłum. M. Zawadzka, Kraków 2013, s. 227.

59 Tamże, s. 278. 
samej sytuacji co poeta lub powieściopisarz żyjący w Londynie, Paryżu czy w Wielkiej Brytanii? Moim zdaniem nie ${ }^{60}$.

Pisarze środkowoeuropejscy niemal bez przerwy mierzą się ze stratą: granic państwowych, tożsamości narodowej, ojczystego języka, utraty najbliższych spowodowanej czystkami etnicznymi, śmierci w obozach koncentracyjnych i łagrach, stratą domu z powodu przesiedleń, wymuszonej emigracji czy niemożnością edukacji, wykonywania zawodu i publikowania. Magris jednym zdaniem określił to, co zazwyczaj umyka badaczom środkowoeuropejskości: „Poszukiwanie tożsamości kryjące się w »chciałbym wam powiedzieć« determinuje również koncentrowanie się analizy na procesie odejmowania, definicji za sprawą negacji”" ${ }^{\prime}$. Literatura środkowoeuropejska jest często mimowolnym świadectwem wydarzeń historyczno-politycznych. Zamiast nich pojawiają się melancholia, niedopowiedzenia, miejsca pustki i ciszy. Jednak, jak się wydaje, przecenienie kontekstu społeczno-politycznego jako cechy konstytutywnej dla mitu środkowoeuropejskiego niesie ze sobą poważne komplikacje w momencie „transformacji” rzeczywistości. Zmiana kontekstu politycznego pociąga za sobą zmianę czasoprzestrzeni - posttotalitarna stagnacja zamienia się w swoje przeciwieństwo i pędzi ku nowoczesnemu kapitalizmowi, a pęd ten zmierza w jednym kierunku - w stronę Zachodu. Czy zatem Europa Środkowa nadal chce i może nazywać siebie środkiem?

\section{Wspólnota wyobrażona czy doświadczana?}

Rozpad Związku Socjalistycznych Republik Radzieckich na nowo przeformułował granice i tożsamość Europy Środkowej. Lata dziewięćdziesiąte XX wieku to podzwonne tych wydarzeń - między innymi rozpad Czechosłowacji na Republikę Czeską i Republikę Słowacką w 1993 roku czy rozpad Socjalistycznej Federacyjnej Republiki Jugosławii, skutkujący tragiczną wojną na Bałkanach, zakończoną podpisanym pokojem pod koniec 1995 roku. U progu XXI wieku konflikty wydają się cichnąć, jednak - jak się właśnie okazuje - nie na długo. Dochodzi do jeszcze jednej zmiany, którą Škrabec nazywa śmiercią utopii: „,́mierć Europy Środkowej lat osiemdziesiątych jest definitywna. Utopie wyróżniają się tym, że często kończą się w momencie urzeczywistnienia"62. W rozumieniu badaczki utopią drugiej połowy XX wieku było wyzwolenie się państw środkowoeuropejskich spod polityczno-gospodarczego jarzma Związku Radzieckiego. Można przewrotnie zapytać, czy sytuacja politycznego pokoju po trans-

\footnotetext{
Tamże, s. 320.

${ }^{61}$ C. Magris, Mit habsburski w literaturze austriackiej moderny, dz. cyt., s. 304.

62 S. Škrabec, dz. cyt., s. 142.
} 
formacji ustrojowej nie jest przypadkiem największym egzaminem dojrzałości dla państw środkowoeuropejskich, w tym Czech i Polski? Jak pisze Škrabec:

Europa Środkowa jest rezultatem długotrwałej walki z warunkami, które w swej istocie są jej zawsze niesprzyjające i to właśnie ta nieustanna walka jest jednocześnie czynnikiem zapewniającym jej spójność, choć jest to spójność bardzo krucha. Ledwo zniknie zagrożenie zewnętrzne, znika również jedność, rozpadając się na tożsamości indywidualne $e^{63}$.

W nowej rzeczywistości potransformacyjnej zadawano sobie pytania, czy mówienie o Europie Środkowej jako wspólnocie jest ciągle zasadne, skoro coraz wyraźniej zarysowywała się nowa utopia integrująca działania państw środka, a mianowicie Unia Europejska. Jeden z najważniejszych komentatorów potransformacyjnej rzeczywistości kulturowej oraz współzałożyciel ośrodka „Pogranicze - sztuk, kultur, narodów”, Krzysztof Czyżewski, twierdzi, że:

anachroniczne jest wielokrotnie stawiane pytanie: czy Europa Środkowa istnieje, czy nie istnieje. (...) Odpowiedzi, których udzielamy, dotyczą stale przeszłości a nie przyszłości. Daliśmy sobie wmówić, że tutaj, na obszarze między Rosją a Niemcami, mamy ciągle stare, zaległe sprawy do rozwiązania. A może stoją przed nami zupełnie nowe wyzwania? ${ }^{64}$

Gest skierowany ku przyszłości opiera się na krytycznym przepracowaniu i zrozumieniu przeszłości właśnie po to, by tę przeformułowaną mapę Europy lat dziewięćdziesiątych XX wieku jak najlepiej zagospodarować. Etos Bildung, pracy u podstaw i działania edukacyjnego poprzez kulturę i sztukę może uczynić więcej dla mieszkańców Europy Środkowej i Wschodniej niż polityczne diagnozy stawiane tylko na papierze. Czyżewski zainspirowany rozmowami z Miłoszem jest orędownikiem tworzenia tkanki łącznej pomiędzy różnymi wspólnotami, kulturami i wreszcie całymi narodami. Tkanka łączna wiąże się nie tylko z dialogiem i otwarciem na Innego, ale również z odzyskiwaniem dla kultury czasu - czasu, dzięki któremu można wymarzyć sobie nową przyszłość. Kategoria marzenia nie jest jedynie podstawą do tworzenia nowej utopii, ale krytyczną i przemyślaną odpowiedzią na potrzeby i lęki mieszkańców pogranicza. Czyżewski w swoich tezach wychodzi poza binarny dyskurs centrów i peryferii - używa określenia pogranicze, które ma łączyć poprzez budowanie mostów. Już w warstwie samego języka dokonuje się gest autorozpoznania, świadomości miejsca-łącznika, które ma potencjał zniesienia kompleksu niższości, a z wielokulturowości czyni wielogłosową tożsamość.

63 Tamże, s. 31-32.

64 K. Czyżewski, Mate centrum świata, Sejny 2017, s. 56, 57. 
Tak definiowaną pracę i filozofię Maria Dąbrowska-Partyka nazywa świadomością pogranicza ${ }^{65}$, czyli postawą otwarcia, którą wyróżniają autoanaliza i samoakceptacja trwania na pograniczu. Staje się ono przestrzenią wartości alternatywnych zarówno dla kultury centrum, jak i peryferii. Jednocześnie badaczka zauważa, że równolegle w wielu społecznościach istnieje tak zwana świadomość granicy związana z symbolicznym dowartościowaniem własnego istnienia przez określanie siebie jako serca, mostu, przedmurza. W modelu tym "przewagę zyskują mechanizmy kompensacji i przeniesienia" ${ }^{66}$. Te dwie postawy nie są stałe i niezmienne, często wzajemnie się przeplatają. Dąbrowska-Partyka stwierdza jednocześnie, że pogranicze jest pojęciem metaforycznym z jednej strony odsłania postawę psychologiczno-kulturową jego mieszkańców, a z drugiej może ujawnić się w literaturze pięknej interpretowanej w uniwersum kultury. Badaczka uważa, że:

Geografia pogranicza jest bowiem geografią symboliczną, opisującą przestrzeń wyobraźni; przestrzeń pamięci, skoncentrowanej na specyficznym doświadczeniu swojskości, której istotą jest obcość, zarazem wyostrzona i oswojona codziennym z nią obcowaniem ${ }^{67}$.

Należy zauważyć, że niemal identycznie - z perspektywy metaforologii ${ }^{68}-$ rozpatrywano również Europę Środkową. Oba doświadczenia: środkowoeuropejskości i pogranicza postrzega się jako przestrzeń z nadmiarem historii, może być ona doświadczeniem ekstremalnym zwłaszcza dla tych, których możliwość wyrazu tożsamości była zagrożona.

Dla Czyżewskiego i Dąbrowskiej-Partyki metafora pogranicza szczególnie wyraźnie ujawnia się w Europie Środkowej i na Bałkanach, choć coraz częściej dotyka także Europy Zachodniej. Badacze zwracają też uwagę na czasowość pogranicza, której - podobnie jak czasu środkowoeuropejskiego - nie można ująć w linearny schemat wielkiej historii, lecz w metaforę koła, która dla Czyżewskiego oznacza poruszanie się nie po liniach prostych, ale po łukach: „Oto nasze powracanie, które niestrudzenie mierzyć się musi z nową rzeczywistością

65 Zob. M. Dąbrowska-Partyka, Literatura pogranicza. Pogranicza literatury, Kraków 2004.

66 Tamże, s. 10.

67 Tamże, s. 11.

68 Pojęcia metaforologii używam tu za Hansem Blumenbergiem. Badacz w swojej książce Paradygmaty dla metaforologii uznał metaforę za jedno z narzędzi służących do konceptualizacji rzeczywistości. Metafory nie da się sparafrazować i wytłumaczyć jej znaczenia za pomocą pojęć, ponieważ posiada ona pewien ukryty znaczeniowy naddatek. Metafora jest tym samym świadectwem postrzegania świata przez jej wyrazicieli, implicytnie odkrywa ich światopogląd oraz struktury użycia. Metaforologia wpisana jest również w kontekst historyczny - każda z metafor ma swoją historię użycia i z upływem czasu ulega kolejnym przekształceniom. Przekształcenia te są jednocześnie świadectwem przemian, które zachodzą w samym języku i nazywaniu rzeczywistości. Por. H. Blumenberg, Paradygmaty dla metaforologii, tłum. B. Baran, Warszawa 2017. 
i nowym wyzwaniem" ${ }^{69}$. Odmienne rozumienie metafory okręgu w swoich utworach zaproponował Andrzej Stasiuk, rysując cyrklem na mapie okrąg, którym wyznaczył zasięg Europy Środkowej, przesuniętej na wschód i południe ${ }^{70}$. Tym samym przyczynit się on do odrodzenia mitu mapy i geografii wyobrażonej:

To w końcu mapa jest ostatnim słowem i śmiertelnym całunem zdarzeń. Nawet gdy wszystko minie, koniec można będzie odwzorować na płaszczyźnie, nadając jej nazwę w jakimś przyszłym niewyobrażalnym języku. Ten rodzaj nostalgii tęskni do widnokręgu, który wciąż się odsuwa, a utopia wyobraża sobie spojrzenie, w którym można zawrzeć całość. Widnokrąg umyka i odcina kolejne porcje nieskończoności. Ucieka, jakby robił miejsce dla zdarzen ${ }^{71}$.

Czapliński słusznie zauważył, że Stasiuk, w przeciwieństwie do Czyżewskiego, stworzył dystopię, w której „ambicje zachodnioeuropejskie skazują Środek na poddanie się kolejnemu procesowi kolonizacji. Skumulował więc [Stasiuk M.B.] znaki gorszości, wykorzystując orientalizację jako język samoobrony"72. Opisany przez pisarza widnokrag pozbawiony historii, będący przestrzenią pustą, melancholijną i zapomnianą, koreluje z metaforą przeciągu, który przelatuje przez Europę Środkową ,jako wiatr historii o zaskakująco przewidywalnym kursie: albo w tę, albo we w tę, ale zawsze tędy"73. Podobnie zresztą w latach osiemdziesiątych pisał Hrabal w utworze Kim jestem: „Żyję w kraju, gdzie stale wieje fen, gdzie sytuacje stresowe nie znajdują ukojenia" ${ }^{4}$. Stasiuk zamiast narracji kompensacyjnych ujawnia zaściankowość wyznaczonego przez siebie okręgu, przez który wiatr tylko przewiewa, jego brzydotę, opóźnienie cywilizacyjne i ukryte resentymenty. W latach sześćdziesiątych Josef Kroutvor w eseju Europa Środkowa. Anegdota i historia podobnie opisywał Czechów, jednak ich plebejskość, płaskostopie i zapach kiszonej kapusty wyraził za pomocą ironii, która ów dyskurs niuansowała i chroniła go przed dosłownością tych sformułowań. Stasiuk dekonstruując i dewaluując ideę Środka, nie czuje potrzeby tworzenia pozytywnego języka do mówienia o Europie Środkowej. Wydaje się bowiem, że jego koncepcja opóźnionego widnokręgu pozbawionego histo-

69 K. Czyżewski, dz. cyt., s. 65.

70 „Posługuję się cyrklem jak dawni geografowie, odkrywcy i wodzowie starych kampanii: mierzę nim odległość. (...) Wbijam więc igłę w miejscu, gdzie teraz jestem, i wszystko wskazuje na to, że pozostanę. Drugie ramię ustawiam tam, gdzie się urodziłem i spędziłem większą część życia. (...) Między moim Wołowcem a Warszawą jest w linii prostej circa trzysta kilometrów. Oczywiście, nie mogę oprzeć się pokusie i wykreślam wokół Wołowca trzystukilometrowy krąg, żeby określić swoją środkową Europę". A. Stasiuk, Dziennik okrętowy [w:] J. Andruchowycz, A. Stasiuk, Moja Europa. Dwa eseje o Europie zwanej Środkowa, Wołowiec 2018, s. 85.

71 Tamże, s. 102-103.

72 P. Czapliński, dz. cyt., s. 260.

73 Tamże, s. 89.

74 B. Hrabal, Kim jestem, tłum. A. Jagodziński [w:] Hrabal, Kundera, Havel... Antologia czeskiego eseju, oprac. J. Baluch, Kraków 2001, s. 31. 
rii właśnie w języku negacji i deformacji zakotwicza indywidualny i niedający się podporządkować Zachodowi charakter.

Termin „Europa Środkowa” i składający się na niego mit środkowoeuropejski w czasach najnowszych ciagle bowiem poszukuje swojego języka i cech charakterystycznych. Można odnieść wrażenie, że literatura czeska wytwarza go rzadziej, choć pojawiają się godne uwagi wyjątki. Za przykład może służyć proza Jáchyma Topola, jednego z najważniejszych twórców współczesnej literatury czeskiej, który tożsamość potransformacyjną swojego narodu wiąże z przepracowaniem tak tragicznej dla tego regionu historii i kompleksów. W Nocnej pracy na przykładzie nienazwanej typowej środkowoeuropejskiej wsi z kościołem i gospodą (położonej gdzieś koło Niemiec i Polski) Topol tworzy osobną przestrzeń magiczną i pyta o istnienie w ludziach pierwiastka zła. Jaroslav Rudiš i jego Grandhotel to kolejny przykład wykorzystania ironii i anegdoty w pisaniu o XX-wiecznych tragediach, między innymi trudnym sąsiedztwie Czechów z Niemcami sudeckimi. Literatura zakreśla koła i w zależności od prądów politycznych i epoki, w której przyszło tworzyć jej autorom, cały czas poszerza i modyfikuje granice myślenia o tożsamości wspólnotowej, ale też tej jednostkowej. Wszystkie przeobrażenia narracji o Europie Środkowej ukazują jednocześnie stan i świadomość dzisiejszej kultury.

Coraz popularniejsze staje się niuansowanie "geograficzne” literatury pięknej za pomocą określeń w rodzaju literatura małych ojczyzn, centra i peryferie czy pogranicze. Literatura pogranicza zresztą ukrywa w sobie ogromny potencjał. Wzywa ona bowiem do autentycznego sąsiedztwa i obcowania z Innym, czyli ustanawiania własnej tożsamości „w ścisłej relacji ze zbiorowością?75. Jednak, jak zauważa Dąbrowska-Partyka, „nie jest ona wspólnotą wyobrażoną, lecz wspólnotą doświadczaną, co nadaje jej rys egzystencjalnej autentyczności: nakazuje solidarność z człowiekiem, a nie - z narodem czy ludzkością"76.

Potencjał, który niesie ze sobą siła wyobraźni, czy też marzenia, jeśli posłużyć się językiem Krzysztofa Czyżewskiego, subwersywnie przenosiły literackie utopie i mitologie środkowoeuropejskie do surowej i poranionej przez historię rzeczywistości. Mit środkowoeuropejski oscyluje między gestem wyzwolenia się spod jarzma imperialnej polityki a tendencją do monopolizowania postulatów czy też cech, którymi powinna wyróżniać się kultura i literatura środkowoeuropejska. Próba rozpoznania przeobrażeń mitu, a więc narracji tożsamościowej Polaków i Czechów, stawia przed badającym wyzwanie tak ogromne, rozdzielone między wiele dyscyplin naukowych i otwierające ciągle mnożące się konteksty, że sama narracja o micie środkowoeuropejskim skazana jest na wiele uogólnień, uproszczeń, klasyfikacji i nie zawsze fortunnych porównań. Wydaje się, że to droga, której nie sposób uniknąć i która jednocześnie daje truistyczną lekcję, a mianowicie - mit środkowoeuropejski jest niedefiniowalny,

\footnotetext{
M. Dąbrowska-Partyka, dz. cyt., s. 65.

76 Tamże.
} 
obejmuje każdą dziedzinę życia, jest zatem w samej istocie aporetyczny. Jednak nie sposób odmówić mu potencjału wspólnotowości, począwszy od wyobrażenia, poprzez literacką realizację, aż po konkretne doświadczenie rzeczywistości środkowoeuropejskiej.

Co zatem o owej wspólnotowości w pierwszych dwóch dekadach XXI wieku może mówić oddalanie się od predykatu środkowoeuropejskiego, które najpełniej wyraża się przez notorycznie powtarzane pytanie: czy Europa Środkowa jeszcze istnieje? A jeśli nagle istnieć przestała, to kim jest dzisiaj? Dokonuję świadomej personifikacji Europy Środkowej, bo przecież nie jest nią pojęcie, nawet najdoskonalej wyobrażone i wyrażone, a konkretne relacje międzyludzkie doświadczane również dzięki literaturze i za jej pomocą. Le Rider postawił niezwykle zasadne pytanie o tożsamość Środkowoeuropejczyka: „Czy sceptycyzm wobec Europy Środkowej - Mitteleuropy nie jest oznaką jakiegoś głębszego eurosceptycyzmu? Czy Europa Środkowa może czuć się europejska, skoro nie czuje się środkowoeuropejska?"77.

Aktualna geografia wyobrażona postawiła za cel jak najściślejszą integrację w ramach Unii Europejskiej. Czas środkowoeuropejski gwałtownie przyspieszył, by ziścić kolejne marzenie, zmazać piętno peryferii, zależności i opóźnienia. Choć przecież dysonans bycia w nieustannym niedoczasie pozostał. „Nowa” schizofreniczna czasoprzestrzeń może stać się źródłem kolejnych problemów tożsamościowych, kompleksów i mechanizmów obronnych nakazujących zamykanie się w bezpiecznej świadomości granicy, a nie ryzykownego pogranicza. Literatura potrafi niuansować te opozycje, oscyluje bowiem między „warunkami zewnętrznymi” a „zachowaniem melancholii podmiotu, który swym cienkim głosikiem próbuje się wtrącić do rozmowy"78. I może to wszystko, czym dysponujemy - a to dużo więcej niż każda (tylko pozornie stała) definicja?

\section{Bibliografia}

Anderson B., Wspólnoty wyobrażone. Rozważania o źródtach i rozprzestrzenianiu się nacjonalizmu, tłum. S. Amsterdamski, Kraków 1997.

Andruchowycz J., Stasiuk A., Moja Europa. Dwa eseje o Europie zwanej Środkowa, Wołowiec 2018.

Ash T.G., Czy Europa Środkowa istnieje?, tłum. J. Anders, „Zeszyty Literackie” 1987, nr 17.

Baluch J., Idea „środka" a tożsamość czeskiej kultury [w:] Kundera. Materiaty z sympozjum zorganizowanego w Katowicach $w$ dniach 25-26 kwietnia 1986 r., red. J. Illg, Londyn 1988.

Baluch J., Gierowski P., Czesko-polski stownik terminów literackich, Kraków 2016.

J. Le Rider, dz. cyt., s. 15.

78 B. Hrabal, Kim jestem, dz. cyt., s. 36. 
Blumenberg H., Paradygmaty dla metaforologii, tłum. B. Baran, Warszawa 2017. Brix E., $Z$ powrotem w Europie Środkowej. Eseje i szkice, tłum. A. Śliwa, Kraków 2012.

Cichocki M., Pótnoc i Potudnie. Teksty o polskiej kulturze i historii, Warszawa 2018.

Czapliński P., Poruszona mapa. Wyobraźnia geograficzno-kulturowa polskiej literatury przetomu XX i XXI wieku, Kraków 2017.

Czyżewski K., Linia powrotu. Zapiski z pogranicza, wstęp P. Huelle, Sejny 2008. Czyżewski K., Mate centrum świata. Zapiski praktyka idei, Sejny 2017.

Dąbrowska-Partyka M., Literatura pogranicza. Pogranicza literatury, Kraków 2004. Dylematy wielokulturowości, red. W. Kalaga, Kraków 2004.

Europa Środkowa, bijące serce kontynentu. Rozmowa z Jiř́m Trávničkiem, http:// www.presseurop.eu/pl/content/article/251081-europa-srodkowa-bijace-serce-kontynentu, dostęp: 1.08.2017.

Europa Środkowa - nowy wymiar dziedzictwa. Materiaty międzynarodowej konferencji zorganizowanej w dniach 1-2 czerwca 2001, red. J. Purchla, Kraków 2002.

Fiut A., Być (albo nie być) Srodkowoeuropejczykiem, Kraków 1999.

Graczyk E., Dyskusja o Srodku Europy [w:] Kundera. Materiaty z sympozjum zorganizowanego $w$ Katowicach $w$ dniach 25-26 kwietnia 1986 r., red. J. Illg, Londyn 1988.

Hašek J., Przygody dobrego wojaka Szwejka podczas wojny światowej, tłum. P. Hulka-Laskowski, Warszawa 1980.

Hrabal B., Piękna rupieciarnia, tłum. A. Kaczorowski, J. Stachowski, Wołowiec 2019.

Hrabal B., Zbyt gtośna samotność, tłum. P. Godlewski, Izabelin 2003.

Hrabal, Kundera, Havel... Antologia czeskiego eseju, oprac. J. Baluch, Kraków 2001.

Illg J., Dyskusja o Środku Europy [w:] Kundera. Materiaty z sympozjum zorganizowanego w Katowicach $w$ dniach 25-26 kwietnia 1986 r., red. J. Illg, Londyn 1988.

Jagodziński A.S., Milan Kundera w polemikach [w:] Kundera. Materiaty z sympozjum zorganizowanego $w$ Katowicach $w$ dniach 25-26 kwietnia 1986 r., red. J. Illg, Londyn 1988.

Kafka F., Most, tłum. R. Karst [w:] tegoż, Okno na ulice i inne miniatury, thum. R. Karst, A. Kowalkowski, Gdańsk 1996.

Kowalczyk A.S., Kryzys świadomości europejskiej w eseistyce polskiej lat 1945-1977 (Vincenz, Stempowski, Mitosz), Warszawa 1999.

Kroutvor J., Europa Środkowa: anegdota i historia, tłum. J. Stachowski, Izabelin 1998.

Kundera M., Sztuka powieści, tłum. M. Bieńczyk, Warszawa 2015.

Kundera M., Zachód porwany albo tragedia Europy Środkowej, „Zeszyty Literackie” 1984, nr 5.

Le Rider J., „Mitteleuropa”, środkowoeuropejski miejsce pamięci, tłum. O. Mastela, „Pamiętnik Literacki” 2013, nr 4. 
Lipszyc A., Apokaliptyczna precyzja, czyli Austria „irret in orbe ultima”, posłowie [w:] M. Perloff, Ostrze ironii. Modernizm w cieniu monarchii habsburskiej, tłum. M. Płaza, Wrocław 2018.

Macura V., Sen o Evropě [w:] tegoż, Český sen, Praha 1998.

Magris C., Dunaj, tłum. A. Osmólska-Metrak, J. Ugniewska, Kraków 2018. Magris C., Mit habsburski w literaturze austriackiej moderny, tłum. E. Jogałła, J. Ugniewska, Budapeszt-Syrakuzy-Kraków 2019.

Magris C., O demokracji, pamięci i Europie Środkowej, tłum. J. Ugniewska, Kraków 2016.

Miłosz C., Rodzinna Europa, Kraków 2001.

Miłosz C., Rozmowy zagraniczne 1979-2003, tłum. M. Zawadzka, Kraków 2013.

Nieuchwytny środek (Europy), „Herito” 2013, nr 10.

Palacký F., Dèjiny národu českého v Čechách a na Moravě dle pưvodních pramenů, t. 1, Praha 1948.

Parfianowicz-Vertun W., Europa Środkowa w tekstach i dziataniach. Polskie i czeskie dyskusje, Warszawa 2016.

Pavel O., Śmierć pięknych saren, tłum. A. Czcibor-Piotrowski, Warszawa 2015.

Perloff M., Ostrze ironii. Modernizm w cieniu monarchii habsburskiej, tłum. M. Płaza, Wrocław 2018.

Podraza A., Europa Środkowa jako region historyczny, referat wygłoszony podczas 17. Powszechnego Zjazdu Historyków Polskich, Kraków 15-18 września 2004, http://jazon.hist.uj.edu.pl/zjazd/materialy/podraza.pdf, dostęp: 1.08.2017.

Rybicka E., Geopoetyka. Przestrzeń i miejsce we wspótczesnych teoriach i praktykach literackich, Kraków 2014.

Schulz B., Sanatorium pod Klepsydrą, Kraków 2008.

Sepioł J., Smutek Wyszegradu, „Herito” 2013, nr 10.

Škrabec S., Geografia wyobrażona. Koncepcja Europy Środkowej w XX wieku, tłum. R. Sasor, Kraków 2014.

Škvorecký J., Tchórze, tłum. E. Witwicka, Katowice 1970.

Szymankiewicz B., Bruno Schulz - pisarz środkowoeuropejski?, „Zeszyty Naukowe Towarzystwa Doktorantów Uniwersytetu Jagiellońskiego” 2016, nr 4.

Thompson E., Historia Europy Środkowej jako narracja postkolonialna. Rzeczy wspólne, http://rzeczywspolne.pl/pismo/rzeczy-wspolne-8-22012/\#, dostęp: 1.08.2017.

Tożsamość w czasach zmiany. Rozmowy w Castel Gandolfo, przygotowanie i przedmowa K. Michalski, tłum. S. Amsterdamski i in., Kraków 1995.

Unos středni Evropy, rozmowa V. Kučery z J. Rychlíkiem, V. Bělohradskim i P. Hlaváčkiem, https://ct24.ceskatelevize.cz/archiv/1508592-unos-stredni-evropy, dostęp: 10.02.2019.

Wiegandt E., Austria Felix, czyli o micie Galicji w polskiej prozie wspótczesnej, Poznań 1988.

Wiegandt E., Mit Galicji w polskiej prozie wspótczesnej (rekonesans tematologiczny), „Teksty: teoria literatury, krytyka, interpretacja” 1979, nr 5. 
Woldan A., Mit Austrii w literaturze polskiej, http://www.polska-niemcy-interakcje. pl/articles/show/26, dostęp: 28.05.2019.

Zenderowicz R., Środkowoeuropejskość jako transnarodowa tożsamość [w:] Europa Środkowa. Salon czy przedpokój Europy?, red. A.K. Gogacz, Łódź 2010.

Zimand R., Dyskusja o Środku Europy [w:] Kundera. Materiaty z sympozjum zorganizowanego $w$ Katowicach $w$ dniach 25-26 kwietnia 1986 r., red. J. Illg, Londyn 1988. 